\title{
Workshop Evaluasi Terhadap Sekolah Khusus Olahragawan PPLP NTB
}

\author{
Soemardiawan $^{1}$ dan Susi Yundarwati ${ }^{2}$ \\ umanksoemardiawan84@gmail.com
}

\begin{abstract}
Abstrak: Workshop evaluasi terhadap sekolah khusus olahragawan PPLP NTB, PPLP NTB merupakan salah satu wadah untuk atlet di Nusa Tenggara Barat. Sekolah ini didirikan sebagai wahana Training Center calon atlet agar memiliki prestasi yang memuaskan, baik di tingkat nasional maupun internasional. Metode yang diterapkan dalam kegiatan ini adalah Desain evaluasi menggunakan model CIPP (Contex, Input, Proces, dan Product) yang dikembangkan oleh Stufflebeam (1985). Model ini memiliki kelebihan dibandingkan model lainnya karena dapat melihat keberhasilan program secara lebih komprehensif, tidak hanya melihat keberhasilan program dari tujuan semata, tetapi mulai dari konteksprogram, input, proses, dan produk secara menyeluruh. Metode yang digunakan dalam pengumpulan data berupa: angket, wawancara dan dokumentasi. Metode ini digunakan untuk menggali data (indepht) yang lebih mendalam yang tidak diperoleh dari pertanyaan dalam angket. Wawancara ditujukan kepada kepala sekolah, pelatih, guru, alumni, dan siswa guna melengkapi data yang digunakan dalam angket. Dokumentasi digunakan untuk menjaring data, meliputi: latar belakang (karakteristik) pelatih, guru, data nilai akhir ujian nasional siswa, prestasi olahraga yang diraih atlet, latar belakang siswa (cabang olahraga, asal daerah). Hasil akhir dari kegiatan penelitian pengabdian ini adalah sebagai wahana Training Center calon atlet agar memiliki prestasi, pembangunan bidang olahraga dilaksanakan melalui berbagai program kegiatan, baik yang bersifat olahraga massal, pembibitan, maupun prestasi. Untuk mendorong keberhasilan olahraga ditanah air, pemerintah telah memberikan kesempatan dan layanan pendidikan kepada segenap pemuda untuk mengikuti pendidikan olahraga bagi yang memiliki bakat olahraga melalui sekolah atlet sekolah khusus olahragawan PPLP NTB didaerah mataram yaitu jalan Pemuda Gomong Mataram.
\end{abstract}

\section{Kata Kunci : Workshop, evaluasi, Sekolah Khusus Olahraga, PPLP NTB.}

\section{PENDAHULUAN}

Pembangunan di bidang olahraga diarahkan untuk menumbuhkan budaya olahraga bagi masyarakat guna meningkatkan kualitas manusia Indonesia sehingga memiliki kesehatan dan kebugaran. Di samping itu, pembangunan olahraga dapat meningkatkan sportivitas, disiplin, dan membangkitkan jiwa nasionalisme. Pembangunan bidang olahraga dilaksanakan melalui berbagai program kegiatan, baik yang bersifat olahraga massal, pembibitan, maupun prestasi. Untuk mendorong keberhasilan olahraga ditanah air, pemerintah telah memberikan kesempatan dan layanan pendidikan kepada segenap pemuda untuk mengikuti pendidikan olahraga bagi yang memiliki bakat olahraga melalui sekolah atlet.

PPLP NTB merupakan salah satu wadah untuk atlet di Nusa Tenggara Barat. Sekolah ini didirikan sebagai wahana Training Center calon atlet agar memiliki prestasi yang memuaskan, baik di tingkat nasional maupun internasional. Melalui PPLP NTB ini, diharapkan Indonesia memiliki bibit-bibit unggul yang mampu berkompetisi dengan atlet-atlet lainnya di dapat menemukana atlet atlet yang prestasi dunia. Untuk meningkatkan kemampuan mental, fisik, dan teknis, PPLP NTB perlu diberikan program pembinaan dan diklat yang mantap, terorganisir, terarah, sistematis, dan komprehensif agar terbentuk atlet yang tangguh berdaya juang tinggi dalam meraih prestasi. Melalui pembinaan dan penggemblengan di PPLP NTB, siswa diharapkan memiliki disiplin, sportif, achievement motivation, produktif, dan profesional sehingga dapat meraih prestasi olahraga yang membanggakan di tingkat internasional. Berdasarkan uraian di atas, dipandang perlu dilakukan evaluasi terhadap 
program pada PPLP NTB. Melalui evaluasi ini diharapkan dapat diketahui -program pembinaan, pelatihan, dan pendidikan efektif dijalankan sesuai dengan tujuan yang diharapkan. Selain itu, hasil evaluasi ini diharapkan dapat memberikan gambaran sekaligus masukan kebijakan bagi Menpora dalam melakukan perbaikan pada di PPLP NTB pada khususnya, dan sekolah atlit lainnya di daerah pada umumnya.

\section{METODE PELAKSANAAN PROGRAM PENGABDIAN MASYARAKAT}

Hasil akhir dari kegiatan penelitian pengabdian ini adalah sebagai wahana Training Center calon atlet agar memiliki prestasi, pembangunan bidang olahraga dilaksanakan melalui berbagai program kegiatan, baik yang bersifat olahraga massal, pembibitan, maupun prestasi. Untuk mendorong keberhasilan olahraga ditanah air, pemerintah telah memberikan kesempatan dan layanan pendidikan kepada segenap pemuda untuk mengikuti pendidikan olahraga bagi yang memiliki bakat olahraga melalui sekolah atlet sekolah khusus olahragawan PPLP NTB didaerah mataram yaitu jalan Pemuda Gomong Mataram.

\section{Persiapaan Workshop evaluasi}

Tahapan persiapan merupakan tahapa awal seblum melakukan pelaksanaan program pengabdian kepada mayarakat. Dalam tahapan ini ada beberapa hal yang dilakukan yakni koordinasi internal, dilakukan oleh tim untk melaksanakan secara konseptual, operasional, serta job description masing masing anggota, penentuan dan rekrutment peserta pelatihan dalam perekrutan peserta dipersyaratkan memiliki keterampilan yang memadai dalam bidang

Desain evaluasi menggunakan model CIPP (Contex, Input, Proces, dan Product) yang dikembangkan oleh Stufflebeam (1985). Model ini memiliki kelebihan dibandingkan model lainnya karena dapat melihat keberhasilan program secara lebih komprehensif, tidak hanya melihat keberhasilan program dari tujuan semata, tetapi mulai dari konteksprogram, input, proses, dan produk secara menyeluruh. Metode yang digunakan dalam pengumpulan data berupa: angket, wawancara dan dokumentasi.
2. Pelaksanaan Pelatihan Pengabdian ini dilaksanakan di sekolah atlet sekolah khusus olahragawan PPLP NTB didaerah mataram yaitu jalan Pemuda Gomong Mataram.pada bulan April tahun 2020 sampai dengan selesai.

\section{1) Peyajian Materi}

Materi yang disajikan terkait dengan pengenalan Penyaji materi adalah tim pengabdi sendiri disesuaikan dengan bidang keahlian masing-masing. Materi yang tersajikan sebanyak 6 (enam) bahasan yang masing-masing disajikan oleh anggota Tim Pengabdi sesuai bidang yang bersangkutan. Berikut tabel daftar materi dan pematerinya yang telah terlaksana dalam program PPM ini

\begin{tabular}{|c|c|c|}
\hline $\begin{array}{c}\text { Jenis } \\
\text { kegiatan }\end{array}$ & Pokok bahasan & pemateri \\
\hline 1 & $\begin{array}{l}\text { Hakekat Sekolah } \\
\text { khusus Olahraga } \\
\text { SKO PPLP NTB }\end{array}$ & Dr. Soemardiawan, M.Pd \\
\hline 2 & $\begin{array}{l}\text { Pelatihan } \\
\text { Kondisi Fisik }\end{array}$ & Dr, Maulidin, M.Pd \\
\hline 3 & $\begin{array}{l}\text { Hakekat } \\
\text { Motivasi Prestasi }\end{array}$ & Susi Yundarwati, M.Pd \\
\hline 4 & $\begin{array}{l}\text { Hakekat } \\
\text { informasi dan } \\
\text { komunikasi }\end{array}$ & Susi Yundarwati, M.Pd \\
\hline 5 & $\begin{array}{l}\text { Hakekat Sosial } \\
\text { dan kesehata }\end{array}$ & Dr. Soemardiawan, M.Pd \\
\hline 6 & $\begin{array}{l}\text { Evaluasi Monev } \\
\text { Prestasi Atlet }\end{array}$ & Dr, Maulidin, M.Pd \\
\hline
\end{tabular}

Pelaksanaan program ini melibatkan Atlet PPLP NTB untuk membantu proses pembimbingan dan praktik agar kegiatan dapat berjalan lancar. Kegiatan tanya jawab dilakukan bersamaan dengan penyajian materi. Para peserta dapat langsung berdiskusi dengan para pemateri secara langsung untuk memahamkan materi dan sharing pengalaman terkait dengan masalah yang tengah dibahas dalam materi bersangkutan tentang evaluasi terhadap sekolah khusus olahragawan PPLP NTB.

\section{2) Penugasan Praktik}

Desain evaluasi menggunakan model CIPP (Contex, Input, Proces, dan Product) yang 
dikembangkan oleh Stufflebeam (1985). Model ini memiliki kelebihan dibandingkan model lainnya karena dapat melihat keberhasilan program secara lebih komprehensif, tidak hanya melihat keberhasilan program dari tujuan semata, tetapi mulai dari konteksprogram, input, proses, dan produk secara menyeluruh. Metode yang digunakan dalam pengumpulan data berupa: angket, wawancara dan dokumentasi. Metode ini digunakan untuk menggali data (indepht) yang lebih mendalam yang tidak diperoleh dari pertanyaan dalam angket. Wawancara ditujukan kepada kepala sekolah, pelatih, guru, alumni, dan siswa guna melengkapi data yang digunakan dalam angket. Dokumentasi digunakan untuk menjaring data, meliputi: latar belakang (karakteristik) pelatih, guru, data nilai akhir ujian nasional siswa, prestasi olahraga yang diraih atlet, latar belakang siswa (cabang olahraga, asal daerah).

\section{3) Evaluasi dan Penyempurnaan di PPLP NTB}

Dalam menentukan sampel evaluasi digunakan teknik random sampling (acak). Jumlah sampel diambil 121 siswa (siswa aktif 112, dan alumni 9 orang) dari populasi yang ada.Teknik ini digunakan dengan cara memilih secara acak terhadap tempat penampungan PPLP NTB sehingga diperoleh sampel sebanyak yang dibutuhkan. Sampel untuk pelatih sejumlah 16 orang. Data yang terkumpul diolah, dianalisis dan disajikan secara naratif (deskriptif) yang pemaparannya dengan menggunakan prosentase, tabel dan grafik. Tempat dan waktu studi evaluasi di PPLP NTB, yang dilaksanakan pada bulan april 2020.

\section{4) Refleksi dan Penutupan Program Pengabdian Masyarakat}

Di akhir kegiatan peserta dan Tim melakukan refleksi hasil pelatihan dan para peserta juga memberikan evaluasi akan pada workshop evaluasi ini. Peserta mendapatkan koreksi dan evaluasi secara langsung terkait hasil karya mereka. Setelah semua kegiatan yang telah direncanakan terlaksana, ketua tim Pengabdian Masyarakat menutup program dan memberikan pesan kepada segenap peserta pelatihan untuk menerapkan apa yang telah diakukan oleh atlet seperti pelaksanaan latihan olahraga, sarana dan prasaran dalam agenda wawancara dan sebrkan angket, komunikasi informasi dan sistem sosial, pelayanan kesehatan, pelayanan asrama, sistem pengelolaan sekolah PPLP NTB di mataram.

\section{HASIL DAN PEMBAHASAN}

\section{. Pelaksanaan Latihan Olahraga}

Jam latihan olahraga di siswa PPLP NTB dilaksanakan hampir sama untuk setiap cabang olahraga, yaitu pagi hari sebelum sekolah, yaitu jam 05.00-07.00 dan sore hari jam 14.30-18.00 WIB. Menurut pelatih maupun siswa, jumlah jam latihan olahraga sudah cukup, hanya jeda waktu antara jam latihan olahraga dan jam mulai masuk sekolah dirasa oleh siswa terlalu singkat, sehingga pada saat mengikuti pelajaran di sekolah siswa masih merasa lelah. Bobot latihan dan variasi latihan baik siswa maupun pelatih menyatakan cukup dan baik. Demikian juga metode yang digunakan baik siswa maupun pelatih menyatakan cukup sesuai dan baik. Kendala yang dihadapi dalam pelaksanaan latihan adalah kurang memadainya lapangan/tempat latihan olahraga serta peralatan olahraga. Sebanyak 52.89\% siswa atlet dan $87,50 \%$ pelatih menyatakan lapangan/tempat latihan kurang memadai. Selanjutnya, ketersediaan dan kondisi peralatan olahraga $33.06 \%$ siswa dan $62.5 \%$ pelatih menyatakan peralatan olahraga kurang memadai. Dari hasil wawancara dengan pelatih panahan:

"Untuk cabang Atletik atlet membawa alatalat dari daerah kabupaten masing-masing karena di sini tidak cukup disediakan, lapangan sepakbola belum berstandar nasional dan tidak memadai. sehingga atlet kadang harus berlatih di Gor Turida dengan transportasi ditanggung sendiri, kadangkadang pelatih harus merogoh kocek sendiri untuk membantu transport atlet".

Demikian pula lapangan atletik yang berdebu dan kotor, yang terpakai. Hal ini mengganggu waktu latihan bulutangkis menyebabkan kualitas latihan kurang fasilitas. 
Lapangan kamar tidur yang rusak, kolam renang kotor, hall bocor, dinding berlubang, penerangan kurang. Beberapa cabang olahraga memakai satu tempat olahraga sehingga harus bergantian dan antri, hal ini mengganggu bobot waktu latihan. Salah satu hal yang perlu diperhatikan adalah kompetisi kejuaraan olahraga. Kegiatan ini dapat menguji coba kemampuan para siswa dan melatih mental bertanding. Sebanyak $62.50 \%$ pelatih menyatakan kompetisi kurang, sebaliknya $34.71 \%$ siswa menyatakan cukup dan $38.84 \%$ menyatakanbaik.Hal ini bisa dimengerti karena pelatih lebih tahu kebutuhan kompetisi bagi siswa. Usulan dari pelatih adalah penambahan dana try out minimal 5-6 kali per tahun dan penjadwalan kompetisi tingkat pelajar, even nasionaldan internasional perlu diselenggarakan. Kendala terbesar dalam mengikuti kompetisi ini, baik siswa maupun pelatih menyatakan keterbatasan dana dan proses turunnya tersendatsendat. Disiplin waktu latihan baik siswa maupun pelatih tergolong baik, demikian juga penguasaan teknis pelatih $77.6 \%$ siswa menyatakan baik. Kesiapan programpelatih dinilai baik oleh $64.46 \%$ siswa. Perencanaan program latihan yang dilakukan pelatih bagi sebagian besar siswa (48.76\%) menyatakan cukup terencana dan $43.80 \%$ menyatakan terencana dengan baik. Perencanaan program latihan disusun per tahun meng acu pada kalender Pengurus Besar (PB) setiap cabang olahraga. Program latihan yang sudah terencana ini, akan dapat terlaksana secara optimal namun kembali terbentur masalah lapangan/tempat latihan dan peralatan olahraga yang kurang memadai, serta tidak terpenuhinya kebutuhan kompetisi (try out).

\section{Komunikasi Informasi Dan Sistem Sosial}

Kemudahan siswa dalam memperoleh akses informasi dan komunikasi tentang olahraga sebagian besar sudah cukup (42,15\%). Namun, masih ada siswa yang menyatakan sangat kurang atau sulit yakni sebesar $6,61 \%$. Solusinya, siswa menyarankan agar disediakan fasilitas internet di sekolah, televisi di asrama ditambah serta diberikan majalah atau surat kabar olahraga ke setiap asrama. Hubungan sosial antarsiswa, siswa dan pelatih atlet. PPLP NTB di Nusa Tenggara Barat.. pada umumnya sudah baik. Hal ini dapat diketahui dari hubungan kekerabatan antara para pelatih, sesame siswa (atlit), pengelola/petugas sekolah atau asrama serta dengan lingkungan masyarakat sekitar menunjukkan baik.

Namun, masih ada siswa yang menyatakan hubungan kekerabatan dengan para pelatih kurang, yakni sebanyak 5 orang $(4,13 \%)$ karena masih ada siswa yang belum mengenal lebih dekat dengan pelatih serta ada pelatih yang dinilai oleh siswa pilih kasih. Selain itu,hubungan kekerabatan sesama atlit masih ada yang menyatakan sangat kurang yakni sebesar 1,65\% (2 siswa) dan menyatakan kurang sebesar 4,13\% (5 siswa). Sebagian besar, yakni sebesar 46,28\% (56 siswa) menyatakan hubungan kekerabatan dengan pengelola sekolah/asrama/petugas sekolah sudah baik. Namun, ada yang menyatakan kurang baik, yakni sebesar 10,74\% (13 siswa) sehingga siswa menyarankan agar diadakan refreshing bersama seluruh komponen yang ada atlet. PPLP NTB di Nusa Tenggara Barat..agar terjalin komunikasi dan keakraban yang akan mendukung kelancaran kegiatan pembelajaran maupun latihan. Hubungan kekerabatan dengan lingkungan masyarakat sekitar sudah cukup baik karena sebagian besar siswa, yakni sebesar 56,20\% (68 siswa/atlet) berpendapat cukup. Namun, masih perlu dijalin komunikasi antara penghuni asrama dengan pihak luar.

\section{Pelayanan Kesehatan}

Pelayanan kesehatan di sekolah atlit atlet. PPLP NTB merupakan salah satu wadah untuk atlet di Nusa Tenggara Barat. dirasakan oleh siswa dan pelatih dirasakan sangat kurang. Khususnya dalam hal pengobatan bagi siswa maupun pelatih yang sakit masih belum terlayani dengan baik. Layanan kesehatan belum dapat memenuhi kebutuhan siswa dan pelatih, apabila sakit, apalagi sakit yang agak berat dan rawat inap. Menurut siswa, apabila sakitnya agak berat, siswa harus mengeluarkan biaya sendiri, apalagi harus rawat inap dan ini memberatkan orang tua. Layanan kesehatan yang memadai terhadap siswa maupun pelatih ini menurut mereka diperlukan, mengingat 
dampaknya sangat mempengaruhi prestasi siswa. Pelatih mengharapkan adanya rumah sakit rujukan bagi atlit yang cidera karena ada beberapa cabang olahraga yangrentan terhadap cidera,misalnya cabang olahraga senam, bolavoli, sepakbola Demikian pula dengan asuransi kesehatan atlet. PPLP NTB di Nusa Tenggara Barat. sangat diperlukan. Asuransi kesehatan ini penting karena merupakan jaminan terhadap keselamatan terhadap atlit maupun pelatih. Obat-obatan yang ada di klinik kesehatan sangat kurang. Ada beberapa atlit yang sakit seringkali diberi jenis obat yang sama, mereka hanya diberikan obat yang menurut istilah mereka "obat warung". Menurut para atlit maupun pelatih, sebaiknya di PPLP NTB di Nusa Tenggara Barat ada dokter atau petugas klinik yang jaga setiap hari 24 jam untuk mengantisipasi keadaan yang tidak diinginkan. Selama ini, siswa tidak mengenal jadwal dokter jaga dan tidak memahami hak-hak layanan apa yang harus diperoleh. Tampaknya, sosialisasi terhadap layanan kesehatan masih rendah. Menu makanan yang disajikan kepada siswa maupun pelatih dirasakan sudah cukup.

Mereka memperoleh jatah makan 3 kali dalam sehari. Menu yang disajikan disarankan untuk lebih bervariasi, tidak monoton yang mengakibatkan atlit kurang selera makan. Demikian pula untuk tempat peralatan makan dan cucian terkesan mengganggu selera makan, mungkin karena letaknya di depan sementara perawatan gedung kurang sehingga tampak kumuh. Menurut siswa, "tempat makan (ruang makan)terasa kurang nyaman dikarenakan ada tempat yang kotor (berair)". Gizi menurut penilaian para pelatih maupun siswa/ atlet sudah dirasakan cukup baik. Ketepatan waktu makan terhadap atlit maupun pelatih sudah cukup baik. Mengenai rekreasi (refreshing) dirasakan menurut siswa masih kurang. Di PPLP NTB di Nusa Tenggara Barat rekreasi hanya 1 kali dalam setahun, inipun tidak menentu. Mereka mengharapkan ada rekreasi untuk mengusir rasa jenuh atau bosan. Bila perlu, kegiatan rekreasi dilakukan minimal 2 kali dalam setahun. Hal ini bertujuan untuk menghilangkan kejenuhan para atlit maupun pelatih karena biasanyasetelah melakukan rekreasi para atlit maupun pelatih ada rasa gairah kembali untuk melakukan latihan atau uji tanding.

\section{Pelayanan Asrama}

Sebagian Besar siswa menyatakan fasilitas tempat tidur dan alat-alat perlengkapan tidur kurang memadai. Siswa mengusulkan agar kenyamanan waktu istirahat para siswa ditingkatkan. Kasur atau alas tidur yang ada menurut merekaumumnya sudah tipis, lepek atau lusuh; begitu juga sprei ataupun gorden sudah lusuh. Di ruang tidur tidak ada $\mathrm{AC}$, ruangan tidur relatif panas. Hal ini diperkuat salah seorang pelatih, pada dalam wawancara tanggal 17 September 2019 PPLP NTB di Nusa Tenggara Barat. yang menyatakan, "Bagaimana atlet mau nyaman kalau 1 kamar 4 orang. AC tidak ada, kabel-kabel dan stop kontak sudah gak teratur, ..." Sejumlah 42.15\% siswa menyatakan bahwa fasilitas penerangan kurang memadai, lampu sering mati dan sering terlambat mengganti. Saran-saran yang dapat diusulkan oleh agar lampu layanan penerangan di kamar ditingkatkan.

Hasil wawancara mendalam, baik tehadap siswa/atlet, pelatih dan guru, juga mengindikasikan hal yang sama. Demikian pula layanan terhadap fasilitas air. Sebagian besar siswa/atlet menyatakan fasilitas air masuk kategori kurang memadai. Hal ini sesuai dengan saransaran yang dapat dijaring dari para siswa/atlet,yangmengemukakan agar lampu penerangan di kamar ditingkatkan. Dalam kaitan ini, disebutkan bahwa air juga sering tidak mengalir. Jumlah kamar tidur ada 24 buah, sedangkan kamar mandi yang dapat dipakai hanya 3 kamar. Hal ini sangat mengganggu, terutama di pagi hari siswa saling berebut tempat mandi sehingga sering terlambat ke sekolah karena harus antri saat mandi. Dari hasil wawancara dengan pelatih Atletik menyatakan:

\footnotetext{
"Bagaimana atlet mau nyaman, kalau 1 kamar 4 orang. AC tidak ada, kabel-kabel dan stop kontak sudah tidak teratur, pompa air sering mati. Jumlah anak 24, kamar mandi/WC cuman 3".
} 
Sebagian besar, siswa menyatakan fasilitas tempat belajar di kamar kurang memadai. Siswamenyarankan agar tempat belajar diperbaiki, ada pula yang tidak memiliki tempat belajar atau kalaupun ada, seperti meja, kondisinya sudah rusak dan sebenarnya sudah kurang layak pakai. Atap di ruang tempat tidur ada yang bolong, pernah terjadi binatang musang jatuh ke tempat tidur. Selain itu, kucing pun seringkali meniduri baju bersih, sedangkan lemari yang ada sudah jelek. Berkaitan ketenangan/ ketertiban/keamanan, umumnya relative memadai. Walaupun ada kasus, misalnya baju dan sepatu sering hilang, ketenangan kadang terganggu. Penilaian siswa terhadap kegiatan belajar di sekolah meliputi penguasaan materi, ketepatan waktu, sistematika penyajian, penggunaan metode dan alat bantu pembelajaran, penampilan guru, penggunaan bahasa, pemberian motivasi belajar dan pencapaian tujuan belajar rata-rata siswa berpendapat $68,13 \%$ menyatakan memadai, dan $42,63 \%$ menyatakan kurang memadai. Berdasarkan gambaran data di atas terlihat bahwa sebagian besar siswa menyatakan bahwa kegiatan pembelajaran di sekolah memadai.

Namun demikian, cukup banyak yang menyatakan bahwa pembelajaran di sekolah kurang memadai. Ada dua item pertanyaan angket yang dinilai kurang memadai, yaitu penggunaan metode/alat bantu pembelajaran dan pencapaian tujuan belajar. Siswa menyatakan bahwa penggunaan metode/alat bantu pembelajaran (66\%) kurang memadai dan pencapaian tujuan pembelajaran kurang memadai (64\%). Ada dua hal lain yang patut diperhatikan, yaitu ketepatan waktu belajar guru dan sistematika penyajian dalam pembelajaran. Pada kedua hal tersebut, para siswa hampir berimbang menyatakan telah memadai dan kurang memadai, walaupun kecenderunganpenilaian menunjukkan bahwa kedua hal tersebut telah memadai. Dilihat dari prestasi akademik yang diukur dari nilai akhir ujian nasional menunjukkan bahwa prestasi akademik tergolongcukup, walaupunbelum memperlihatkan kondisi sesungguhnya dari siswa. Hasil angketmenunjukkan 52,89\% siswaberpendapatpencapaian tujuan belajar disekolah kurang tercapai. Prestasi terhadap olahragayang diukur dari keikutsertaan kejuaraan/kompetisi dan perolehan medali tergolong cukup

\section{Sistem Pengelolaan Sekolah Pplp Ntb Di Mataram}

PPLP NTB di Nusa Tenggara Barat belum memiliki sistem pengelolaan kelembagaan yang jelas, fokus, dan terpadu setelah otonomi daerah digulirkan tahun 2022, khususnya dalam pengelolaan asset/sarana prasarana, pembinaan siswa dan

pengembanganprogramnya.Tampaknya, banyak unsur yang terkait dengan penyelenggaraan PPLP NTB di Nusa Tenggara Barat, yaitu Dinas Olahraga dan Pemuda NTB, Menegpora, Mendiknas/Dinas Pendidikan Propinsi NTB, Pengurus Besar Cabang Olahraga/KONI/KONI Kabupaten. Masingmasing unsure tersebut memiliki tanggung jawab dan kepentingan yang berbeda walaupun tujuannya sama, yaitu ingin meningkatkan prestasi olahraga di Indonesia. Dinas Olahraga dan Pemuda NTB bertanggung jawab terhadap aset, seperti lahan dan sarana prasarana, Dinas Pendidikan (Dikmenti dan Dikdas) bertanggung jawab dalam kaitan sekolah sepertikurikulum, tenaga pendidik, dan lain-lain yang berkaitan dengan urusan pendidikan (operasional sekolah), Koni/ PB bertanggung jawab dengan urusan yang berkaitan dengan koordinasi prestasi siswa, misalnya dalam kompetisi atau kejuaraan, dan DIKPORA NTB berkaitan dengan pembinaan dan pengembangan siswa termasuk rekrutmen. Tampaknya, banyak unsur dan kepentingan yang terkait dengan PPLP NTB di Nusa Tenggara Barat dan berjalan sendiri-sendiri hingga kini belum ada koordinasi yang baik untuk merumuskan satu sistem penyelenggaraan dan pengelolaan PPLP NTB di Nusa Tenggara Barat yang komprehensif dan diharapkan semua pihak. Seorang mantan pelatih panahan mengatakan bahwa, "Memang serba salah, sekolah atlet Evaluasi terhadap Sekolah Khusus Olahragawan SMP/SMA PPLP NTB di Nusa Tenggara Barat ini milik DIKPORA 
$N T B$, tetapi para siswanya direkrut dari seluruh Indonesia. Apakah mau NTB membiayai keperluan atlet seluruh Indonesia". Untuk mengatasinya tampaknya diperlukan kesepahaman, kerjasama, kesepakatan dan komitmen antarberbagai unsur yang terkait untuk mengatur satu sistem pengelolaan atau penyelenggaraan, dan pembinaan siswa dan sekolah. Keadaan ini telah mengganggu upaya pembinaan dan pengembangan olahraga yang ada di PPLP NTB di Nusa Tenggara Barat.

\section{SIMPULAN}

Berdasarkan hasil evaluasi terhadap PPLP NTB di Nusa Tenggara Barat dapat disimpulkan bahwa PPLP NTB di Nusa Tenggara Barat masih diperlukan dan sesuai dengan kebutuhan dalam pengembangan olahraga di tanah air, kendati pun masih dihadapkan berbagai permasalahan manajemen, yaitu sistem pengelolaan yang tidak jelas terlebih setelah otonomi daerah. PPLP NTB di Nusa Tenggara Barat $\mathrm{n}$ belum memiliki sistem pengelolaan kelembagaan yang jelas, fokus, dan terpadu, khususnya dalam pengelolaan asset/sarana prasarana dan program. Diperlukan kerjasama, kesepakatan, dan komitmen antarberbagai unsur yang terkait dengan pengelolaan sekolah siswa, yaitu Dinas Olahraga dan Pemuda NTB, Menegpora, Mendiknas, Pengurus Besar Cabang Olahraga/KONI/ KONI Kabupaten . Rekrutmen terhadap siswa PPLP NTB di Nusa Tenggara Barat masih lemah, belum sepenuhnya mengacu pada ketentuan yang berlaku dalam rekrutmen siswa sesuai prosedur dan kemampuan fisik, teknis, dan mental yang harus dimiliki oleh calon siswa. Dilihat dari program latihan olahraga yang disusun dan dilaksanakan oleh pelatih di PPLP NTB di Nusa Tenggara Barat oleh siswa (64.46\%) dinilai baik. Perencanaan program latihan yang dilakukan pelatih bagi sebagian besar siswa, yaitu $48.76 \%$ dinilai cukup terencana. Namun demikian, program latihan yang disusun pelatih belum bisa sepenuhnya diimplementasikan karenadukungan dana yang tidak memadai, program latihan yang disusun sering terhambat, kompetisi yang sudah direncanakan sering berubah karena tidak tersedia dana yang cukup. Disiplin waktu latihan baik siswa maupunpelatih baik, demikian juga penguasaan teknis pelatih $77.6 \%$ siswa menyatakan baik. Motivasi belajar siswa di sekolah pada umumnya $(71,07 \%)$ baik, namun demikian, lebih dari 21,49\% kurang, motivasi untuk berlatih olahraga rata-ratabaik. Kurangnya motivasi belajar di sekolah karena siswa kelelahan setelah latihan olahraga. Tampaknya siswa lebih menyukai latihan olahraga daripada belajar di sekolah. Dilihat dari prestasi akademik yang diukur dari nilai akhir ujian nasional menunjukkan bahwa prestasi akademik tergolong cukup, walaupun belum memperlihatkan kondisi sesungguhnya dari siswa. Hasil angket menunjukkan $52,89 \%$ siswa berpendapat pencapaian tujuan belajar di sekolah kurang tercapai, sedangkan prestasi terhadap olahraga yang diukur dari keikut sertaan kejuaraan/kompetisi dan perolehan medali tergolong cukup. Kemudahan dalam memperoleh akses komunikasi dan informasi tentang olahraga dinilai cukup oleh siswa, namun demikian, $28,92 \%$ siswa menyatakan bahwa layanan informasi tentang olahraga masih kurang. Siswa mengharapkan adanya peningkatan akses informasi seperti internet, majalah, dan koran sampai saat ini belum tersedia. Pelayanan terhadap makanan dan gizi yang diberikan kepada siswa dan pelatih dinilai cukup baik demikian pula ketepatan waktu makan juda dinilai cukup. Pelayanan terhadap kesehatan siswa, khususnya layanan dokter, dan obatobatan dinilai kurang, bahkan layanan kesehatan terhadap pelatih $(50 \%)$ dinilaisangat kurang. Hampir seluruh siswa tidakmengetahui jadwal dokter jaga/petugas klinik. Hubungan kekerabatan dengan sesama siswa pada umumnya baik, walaupun masih ada yang kurang yakni hubungan antara siswa senior dan siswa yunior.

Demikian pula hubungan kekerabatan dengan pengelola/ petugas asrama/sekolah dan masyarakat juga baik. Siswa dan pelatih mengharapkan ada rekreasi (refreshing) untuk menghilangkan kejenuhan, sebagian besar siswa dan pelatih menyarankan perlunya rekreasi karena sangat kurang bahkan tidak ada. Sarana prasarana 
olahraga meliputi lapangan (outdoor dan indoor) dan peralatan olahraga di PPLP NTB di Nusa Tenggara Barat dinilai oleh sebagaian besar siswa dan pelatih kurang memadai. Sebanyak $52.89 \%$ siswa, dan $87,50 \%$ pelatih menyatakan lapangan/tempat latihan kurang memadai, demikian pula ketersediaan dan kondisi peralatan olahraga sangat kurang. Untukmengujicobakemampuan siswa dan mental bertanding diperlukan kompetisi, kegiatan ini oleh siswa dan pelatih dinilai kurang bahkan sangat kurang, baik kompetisi nasional maupun internasional. Sebagian besar siswa menyatakan fasilitas tempat/kamar tidurdan alat-alat perlengkapan tidur kurangmemadai.

Siswa menyarankan agar tempat belajar diperbaiki, ada pula yang tidak memiliki tempat belajar atau kalaupun ada seperti meja, kondisinya sudahrusakdan sebenarnya sudah kurang layak pakai. Sejumlah $42.15 \%$

siswa menyatakanbahwafasilitaspenerangan kurang memadai, lampu sering mati dan sering terlambat mengganti. Penilaian terhadap kegiatan belajar di sekolah meliputi penguasaan materi, ketepatan waktu, sistematika penyajian, penggunaan metode, penampilan guru, penggunaan bahasa, dan pemberian motivasi belajar sebagian besar siswa $(68,13 \%)$ berpendapat memadai, namun demikian, yang menyatakan kurang memadai masih tinggi $42,63 \%$. Kegiatan pembelajaran di sekolah yang dinilai kurang memadai dilakukan oleh guru, yaitu 66\% siswa menilai penggunaan metode/alat bantu pembelajaran kurang memadai, dan pencapaian tujuan belajar 64\% siswa menilai kurang memadai.

\section{SARAN}

Perlu disusun kesepakatan baru dalam bentuk MoU yang mengatur pengelolaan PPLP NTB di Nusa Tenggara Barat yang melibatkan Dinas Olahraga dan Pemuda NTB Jakarta, Menegpora, Mendiknas, Pengurus Besar Cabang Olahraga/KONI/KONI Kabupaten, dan berbagai unsur yang terkait lainnya. Perlu disusun pedoman/acuan penyelenggaraan PPLP NTB di Nusa Tenggara Barat yang komprehensif yang dapat dijadikan acuan bagi siapa saja yang membutuhkan informasi. Perlu dikembangkan sistem pembelajaran yang lebih fleksibel sehingga dapat memenuhi kebutuhan belajar siswa yang waktunya sering berbenturan Evaluasi terhadap Sekolah Khusus Olahragawan SMP/SMA PPLP NTB di Nusa Tenggara Barat dengan jadwal latihan/ kompetisi. Misalnya, sistem modul/tutoral. Kesempatan siswa untuk mengikuti kompetisi/kejuaraan perlu ditambah minimal 4-5 kali per tahun karena kegiatan ini dapat menguji kemampuan siswa dan mempersiapkan mental tanding.

Untuk memudahkan akses komunikasi dan informasi perlu disediakan fasilitas internet, pengadaan majalah dan surat kabar olahraga. Perlu diadakan rekreasi baik siswa, pelatih atau lainnya untuk mengurangi kejenuhan agar lebih bergairah. Untuk layanan kesehatan perlunya dokter/petugas klinik jaga yang siap dalam 24 jam untuk mengantisipasi halhal yang tidak diinginkan, serta perlunya askes untuk siswa dan pelatih, penambahan obat-obat, rumah sakit rujukan bagi siswa yang sakit berat maupun yang cidera. Perlu perbaikan lapangan dan peralatan olahraga, ruang makan, tempat tidur, dan asrama. Perlunya penambahan kamar mandi/perbaikan kamar mandi karena jumlah kamar mandi yang ada dengan jumlah siswa kurang seimbang, sebagian WC mampet/rusak. Perlu penambahan lapangan olahraga/tempat latihan karena siswa Ragunan sering berebut dengan klub lain. Fasilitas penerangan perlu ditingkatkan dan sistem instalasi listrik ditata kembali. Fasilitas air perlu ditingkatkan karena sering tidak lancar. Perlu insentif yang layak bagi pelatih untuk mendorong kinerja para pelatih. Terima kasih diucapakan kepada semua pihak yang telah memberi kontribusi terhadap artikel ini. Terima kasih juga diucapkan kepada pengurus dan Redaktur Jurnal Cakrawala Pendidikan.

DAFTAR PUSTAKA 
Mylsidayu dan Kurniawan. Kepelatihan Olahraga. Jakarta : PT Persada, 2015.University Press, 2012.

Tangkudung, James. Kepelatihan Olahraga (Pembinaan Prestasi Olahrga). Jakarta: Cerdas Jaya, 2006.

Tangkudung.J. Kepelatihan Olahraga" Pembinaan Prestasi Olahraga" Edisi II. Jakarta: Cerdas Jaya. 2012

Tangkudung, James. Ilmu Faal Olahraga. Cipta Jaya 2006.

Undang-undang No.23 Tahun 1992 Tentang Kesehatan \& Undang-undang No.29 Tahun 2004 Tentang Praktik Kedokteran", VisiMedia, 9791043604, 9789791043601.

World Health Organization (2005). Promoting Mental Health: Concepts, Emerging evidence, Practice: A report of the World Health Organization, Department of Mental Health and Substance Abuse in collaboration with the Victorian Health Promotion Foundation and the University of Melbourne. World Health Organization. Geneva. 